\title{
Mineralization of Nitrogen in Hydromorphic Soils Amended with Organic Wastes
}

\section{${ }^{1}$ IWEGBUE C.M.A AND; ${ }^{2}$ EMUH, F N; ${ }^{1}$ BAZUNNU, A O; ${ }^{3}$ EGUAVOEN O}

\author{
${ }^{I}$ Department of Chemistry, Delta State University, Abraka P.M.B. 1 Abraka, Nigeria \\ ${ }^{2}$ Department of Crop/Soil Science, Delta State University, Anwai-Asaba Campus, Asaba, Nigeria \\ ${ }^{3}$ Ambrose Alli University, P.M.B 14 Ekpoma, Edo State
}

\begin{abstract}
This paper present the results of nitrogen mineralization in hydromorphic (wetland) soils of the Niger Delta amended with organic wastes. The organic wastes amended soil generally showed a decrease in total inorganic $\left(\mathrm{NO}_{3} \mathrm{~N}+\mathrm{NH}_{3} \mathrm{~N}\right)$ released within first 14 days, which increased thereafter. The nitrogen mineralized during 58 day of incubation ranged from $82.15 \mathrm{mg} \mathrm{kg}^{-1}$ to $281.60 \mathrm{mg} \mathrm{kg}^{-1}$ for fadamal soil, $54.50 \mathrm{mg} \mathrm{kg}^{-1}$ to $197.30 \mathrm{mg} \mathrm{kg}^{-1}$ for meander belt soil and $98.50 \mathrm{mg} \mathrm{kg}^{-1}$ to $320.00 \mathrm{mg} \mathrm{kg}^{-1}$ for Mangrove soil (mangal acid sulphate soils). The order of cumulative nitrogen released in the waste amended soil followed the order: sewage sludge $>$ kitchen waste $>$ poultry manure $>$ oil palm waste $>$ cow manure. Total mineralized $\mathrm{N}$ indicated negative correlation with total organic $\mathrm{N}$ and $\mathrm{C}$ : N ratio. @JASEM
\end{abstract}

Keywords: N-immobilization; Mineralization; Wetland soils; Niger Delta; Nigeria.

The concept of recycling waste nutrients and organic matter implies that agricultural land is feasible and desirable. Land application represents an economically desirable outlet for the producer of waste and a potential cheap source of organic matter and fertilizer elements for landowners. More so, because of the increasing energy requirement for production of synthetic fertilizers, the cost and environmental problems associated with alternative disposal methods. Of the many problems associated with organic farming and various soil management practices, including minimum and no-till system, nutrient cycling in organic waste-treated soils deserved attention. Information on the relative degree of nutrient release (mineralization) and nutrient tiedup (immobilization) in soil treated with various organic waste materials are therefore needed.

The fate of nitrogen in waste amended soil has been documented (Chae and Tabatabai, 1986; Pettygrove et al, 2003; Rubuduka et al, 1993; Murwira and Kitchman, 1993, Kachaka et al, 1993; Iwegbue et al., 2006). Pettygrove et al. (2003) reported that net mineralization in a sandy loam soil (pH7.6) amended with dairy manure water and dairy manure shows that the net mineralization of Nitrogen for dairy manure was rapid during the first 21 days and was slow and variable thereafter. The two manures showed initial net mineralization, then immobilization. For the eight other manures, apparent net mineralization during the first 21 days averaged $15-20 \%$ of the manure organic $\mathrm{N}$. The liquid density, total suspended solid and organic nitrogen were found to be related to the 21 days net mineralization. Chae and Tabatabai (1986) reported that mineralization of nitrogen in soil amended with different waste materials exhibited a slow initial rate, which was indicative of the lag period, followed by rapid increase in rate and subsequent slow $\mathrm{N}$ release. The total nitrogen mineralized from the organic waste materials varied considerably depending on the soil type and organic material.

The kinetics of nitrogen mineralization in organic wastes amended soil have been described with first order reaction kinetics (Chae and Tabatabai, 1986; Cheschair et al., 1986; Murwira and Kirchman, 1993; Christensen and Olesen, 1988) or a set of first order kinetics (Gale and Gilmour, 1986). This communication present the results of mineralization of nitrogen in typical wetland soils of the Niger Delta amended with organic wastes with a view of providing information on crop nitrogen requirement.

\section{MATERIALS AND METHODS}

Three surface soils of $0-15 \mathrm{~cm}$ (Table 1) selected to represent some major soil series in the Niger Delta and include a wide range of chemical and physical properties. The samples were collected at latitude $5^{0}$ $45^{1} \mathrm{~N}$ and longitude $6^{0} 7^{1} \mathrm{E}$, latitude $5^{0} 15^{1} \mathrm{~N}$ and longitude $6^{0} 11^{1} \mathrm{E}$ and latitude $5^{0} 36^{1} \mathrm{~N}$ and $5^{0} 46^{1}$ $\mathrm{E}$ for fadamal soil, meander belt soil and mangal acid sulphate soil respectively Samples of field moist capacity were brought to the laboratory, pass through a $2 \mathrm{~mm}$ screen and divided into 2 portions. One was placed in a polyethylene bag and stored at $4^{0} \mathrm{C}$, and a sub sample of this portion was used in the incubation experiment to study mineralization.

The second portion of soil was air dried at room temperature for $48 \mathrm{~h}$ and stored in a tightly sealed bottle. A sub sample of the air-dried portion was used for the determination of chemical properties.

Sewage sludge was collected from the Shell Petroleum Development Company (SPDC) sewage treatment plant at Edjeba, Warri. To speed up the air- 
drying the sludge was spread on plastic tray $30 \times 50$ $\mathrm{cm}$ placed in well-ventilated hood. A fan was directed towards the hood to enhance evaporation of the liquid. By this procedure, the sludge was normally air-dried with $24-48 \mathrm{~h}$. Thereafter, the material was weighed and was ground to pass $2 \mathrm{~mm}$ sieve.

The kitchen waste, poultry waste, cow manure was collected fresh and dried in a manner similar to that described for sewage sludge samples. After airdrying; they were ground to pass $2 \mathrm{~mm}$ mesh sieve $850(\mu \mathrm{m})$. The sewage sludge and other organic wastes were stored at $4^{\circ} \mathrm{C}$.

In the analysis reported in Table I and II, $\mathrm{pH}$ was determined by a glass electrode (soil/water ratio $1: 2.5)$ sewage sludge before drying and animal manures at waste/water ratio 1:10) (McLean, 1982). Total organic carbon was determined by wet dichromate method of Walkley and Black (Nelson and Sommer, 1982). Total nitrogen was determined by using the semi-macro Kjeldahl method (Bremner and Mulvaney, 1982). Mineral nitrogen was determined by colorimetric method (Keeney and Nelson, 1982) after extraction with $2 \mathrm{M} \mathrm{KCl}$. The particle size distribution was by hydrometer method for silt and clay, and by dry sieving for sand fraction (Reeuwijk, 1995).

The incubation experiment was done in the laboratory of field capacity and at constant temperature of $25^{\circ} \mathrm{C}$. Soil samples (each $100 \mathrm{~g}$ ) were thoroughly mixed with $200 \mathrm{mg}$ dry weight (equivalent to 40 tones per hectare) of the waste and placed $100 \mathrm{ml}$ incubation vessel. Samples for total organic and inorganic nitrogen were taken at day 0 , 14, 28, 42 and 58 days. The total inorganic nitrogen mineralized during incubation was determined after extraction with $2 \mathrm{M} \mathrm{KCl}$ by the procedure previously described.

\section{RESULTS AND DISCUSSION}

The five organic wastes displayed a wide range of net mineralization value in the different soil types (Figures 1, 2 and 3). The organic waste amended soils generally showed a decrease in total amount of inorganic nitrogen $\left(\mathrm{NO}_{3}-\mathrm{N}+\mathrm{NH}_{3}-\mathrm{N}\right)$ released after 14 days and thereafter increase in total amount of inorganic released. This agrees with observations of Haque and Walmsley (1972) who opined that the immobilization of $\mathrm{N}$ during the initial period of incubation, followed by mineralization of $\mathrm{N}$ in the later period. Analysis of variance(ANOVA) at $\mathrm{p}<0.05$, show that the pattern and amount of nitrogen mineralized from the organic wastes studied varied, depending on the waste type and soil to which the material was added. All the waste types showed significant higher amount of nitrogen mineralized compared to the controls. Table 1 and 2 reports some physicochemical properties of the soil and waste types used for the incubation. The results revealed apparent and significant variability in the physicochemical properties of the waste and soil types used for the incubation experiment.

Table 1. Some properties of soil used

\begin{tabular}{|c|c|c|c|c|c|c|c|c|c|c|}
\hline & $\mathrm{pH}$ & $\begin{array}{c}\text { Total N } \\
(\%)\end{array}$ & $\begin{array}{c}\mathrm{NH}_{3-} \mathrm{N} \\
\left(\mathrm{mgkg}^{-1}\right)\end{array}$ & $\begin{array}{c}\mathrm{NO}_{3}-\mathrm{N} \\
\left(\mathrm{mgkg}^{-1}\right)\end{array}$ & $\begin{array}{c}\text { Total } \\
\text { Min-N } \\
\left(\mathrm{mgkg}^{-1}\right) \\
\end{array}$ & $\begin{array}{c}\text { TOC } \\
(\%)\end{array}$ & $\begin{array}{l}\text { Ash } \\
(\%)\end{array}$ & \multicolumn{2}{|c|}{ Texture } & $\mathrm{C}: \mathrm{N}$ \\
\hline \multicolumn{11}{|l|}{ Soil } \\
\hline Famadal soil & 7.16 & 0.06 & 5.25 & 9.76 & 15 & 1.73 & 92.07 & Sandy & & 28.83 \\
\hline $\begin{array}{l}\text { Meander belt } \\
\text { soil }\end{array}$ & 6.31 & 0.13 & 4.68 & 10.92 & 10.92 & 5.24 & 90.96 & $\begin{array}{l}\text { Sandy } \\
\text { loam }\end{array}$ & clay & 40.31 \\
\hline $\begin{array}{l}\text { Mangrove soil } \\
\text { (mangal-acid } \\
\text { sulphate) }\end{array}$ & 6.61 & 0.50 & 40.00 & 60.00 & 100.0 & 12.76 & 78.03 & $\begin{array}{l}\text { Sand } \\
\text { loam }\end{array}$ & clay & 25.48 \\
\hline
\end{tabular}

\begin{tabular}{|c|c|c|c|c|c|c|c|c|}
\hline Wastes & $\mathrm{pH}$ & $\begin{array}{c}\text { Total N } \\
(\%)\end{array}$ & $\begin{array}{c}\mathrm{NH}_{3} \mathrm{~N} \\
\left(\mathrm{mgkg}^{-1}\right)\end{array}$ & $\begin{array}{c}\mathrm{NO}_{3}-\mathrm{N} \\
\left(\mathrm{mgkg}^{-1}\right)\end{array}$ & $\begin{array}{c}\text { Total } \\
\text { Min-N } \\
\left(\mathrm{mgkg}^{-1}\right)\end{array}$ & $\begin{array}{l}\text { TOC } \\
(\%)\end{array}$ & $\begin{array}{l}\text { Ash } \\
(\%)\end{array}$ & $\mathrm{C}: \mathrm{N}$ \\
\hline Cow dung & 12.59 & 1.70 & 265.2 & 244.8 & 510 & 49.17 & 15.23 & 28.92 \\
\hline Poultry manure & 9.54 & 2.24 & 537.6 & 258.8 & 896 & 45.23 & 22.03 & $20 . .19$ \\
\hline Kitchen waste & 7.33 & 2.90 & 1531.2 & 208.1 & 1,740 & 49.81 & 14.13 & 17.18 \\
\hline $\begin{array}{l}\text { Oil palm sludge }+ \\
\text { oil palm waste }\end{array}$ & 6.97 & 1.40 & 492.0 & 98.0 & 392 & 39.30 & 32.25 & 28.07 \\
\hline Sewage sludge & 5.01 & 4.00 & 1650.0 & 1,350 & 3,000 & 46.00 & 20.70 & 11.50 \\
\hline
\end{tabular}


Mineralization of Nitrogen in Hydromorphic.....

Table 3: Amount of $\mathrm{N}$ mineralization with successive incubation period in waste amended wetland soil.

$\mathrm{N}$ Mineralized with successive incubation period (day) specified

\begin{tabular}{llccccc}
\multicolumn{7}{c}{$\left(\mathrm{mgkg}^{-1}\right)$} \\
Soil & Waste & $\mathbf{0 - 1 4}$ & $\mathbf{1 4 - 2 8}$ & $\mathbf{2 8 - 4 2}$ & $\mathbf{4 2 - 5 6}$ & Total \\
Fadamal soil & Cow manure & 0 & 62.20 & 4.69 & 15.26 & 82.15 \\
& Poultry manure & 0 & 76.97 & 38.48 & $19: 25$ & 134.7 \\
& Kitchen waste & 0 & 130.73 & 57.00 & 28.42 & 216.15 \\
& Oil palm waste & 0 & 60.30 & 7.38 & 25.5 & 93.27 \\
& Sewage sludge & 0 & 176.00 & 70.4 & 35.2 & 281.60 \\
& Control & 0 & 3.0 & 2.0 & 2.0 & 3.50 \\
\hline Meander Belt soil & Cow manure & 0 & 27.25 & 18.17 & 9.08 & 54.0 \\
& Poultry waste & 0 & 62.4 & 32.2 & 15.6 & 109.2 \\
& Kitchen waste & 22.41 & 0.00 & 134.48 & 22.41 & 179.3 \\
& Oil palm waste & 0 & 49.04 & 23.48 & 12.04 & 84.56 \\
& Sewage sludge & 0 & 121.21 & 0.97 & 46.55 & 168.78 \\
& Control & 0 & 3.0 & 2.0 & 4.0 & 3.0 \\
\hline Mangrove swamp soil & Cow manure & 0 & 64.88 & 22.44 & 11.22 & 98.50 \\
(mangal acid-sulphate soil) & Poultry waste & 0 & 99.39 & 0 & 38.97 & 138.36 \\
& Kitchen waste & 0 & 130.5 & 1.31 & 127.89 & 259.7 \\
& Oil palm waste & 0 & 49.93 & 17.46 & 13.95 & 81.34 \\
& Sewage sludge & 0 & 2.92 & 28.0 & 0 & 320.00 \\
& Control & 0 & 4.0 & 3.0 & 4.0 & 5.0 \\
\hline
\end{tabular}

Table 3 presents the amount of nitrogen mineralized compared with the successive incubation in the waste amended wetland soils. A shown in table III, no mineralization took place within the first 2 weeks of incubation, except for meander belt soil amended with kitchen waste. The nitrogen mineralized during 58 days incubation ranged from $82.15 \mathrm{mgkg}^{-1}$ to $281.60 \mathrm{mgkg}^{-1}$ for fadamal soil, $54.50 \mathrm{mgkg}^{-1}$ to $197.30 \mathrm{mgkg}^{-1}$ for meander belt soil and $98.50 \mathrm{mgkg}^{-}$ ${ }^{1}$ to $320.00 \mathrm{mgkg}^{-1}$ for mangrove swamp soil. The order of cumulative nitrogen released in the waste amended soils follow the order; sewage sludge $>$ kitchen waste $>$ poultry manure $>$ oil palm waste $>$ cow manure. This contrasts the order of $\mathrm{C}: \mathrm{N}$ ratio of the waste used for the incubation. This is due to the fact that when stabilized organic products with adequate $\mathrm{C}: \mathrm{N}$ ratio $(<20)$ are added to the soil, the mineralization process is enhanced (Nogales et al., 1982) while products with high $\mathrm{C} / \mathrm{N}$ ratio promotes immobilization (Stemmer et al., 1999). The promotion of nitrogen immobilization or reduction of nitrogen mineralization by high $\mathrm{C}: \mathrm{N}$ ratio waste is as a result of the increase in microbial load stimulated by high carbon content. This make such organisms to consume most of the nitrogen meant for mineralization for their own body activity (Brady, 1974).

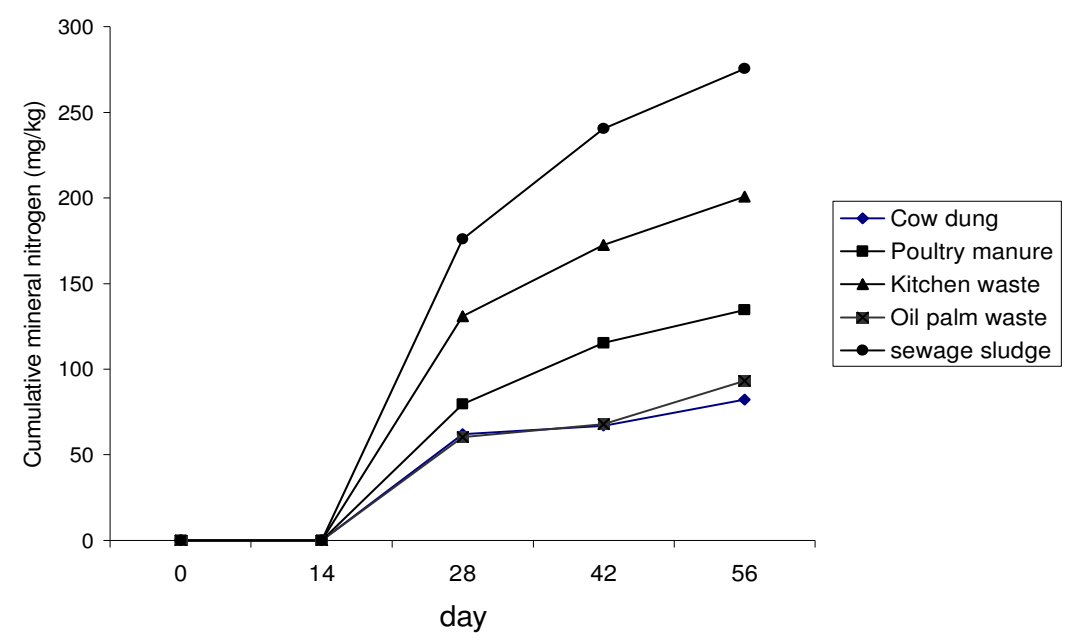

Fig 1: Cumulative nitrogen mineralization in fadamal soils amended with organic wastes.

The mangrove soil (mangal acid-sulphate soil) and fadamal soil showed higher amount nitrogen released compared to the meander belt soil. This due to the high proportion of the sand fraction in these soils.

Chukwujindu, M A I; Emuh, F N; Bazunnu, A O; Osa, E 
Mineralization of Nitrogen in Hydromorphic.....

Our finding agrees with observations of Madrid et al. (2001) who observed that nitrogen mineralization is by far more intense in the sandy soil than clay soil when the soils are amended with municipal waste sludge composts. Higher protection of the organic matter-clay complex makes microbial attack in soil with high clay contents more difficult (Herbert et al., 1991).

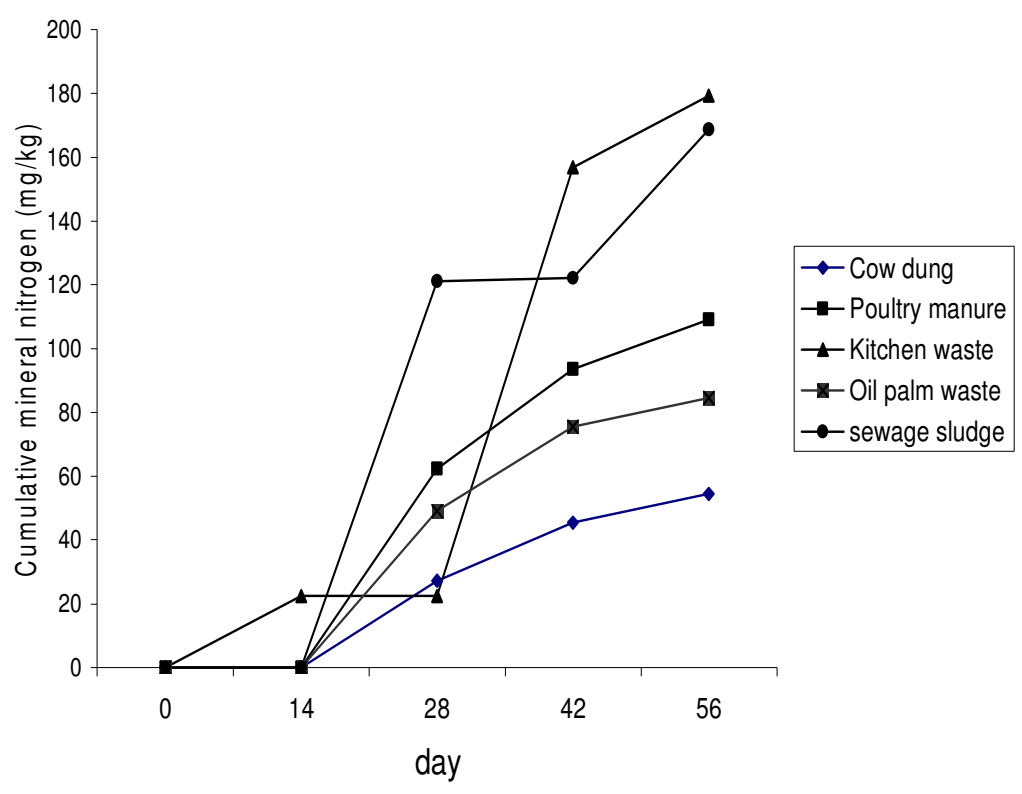

Fig 2: Cumulative nitrogen mineralization in meander belt soil amended with organic wastes

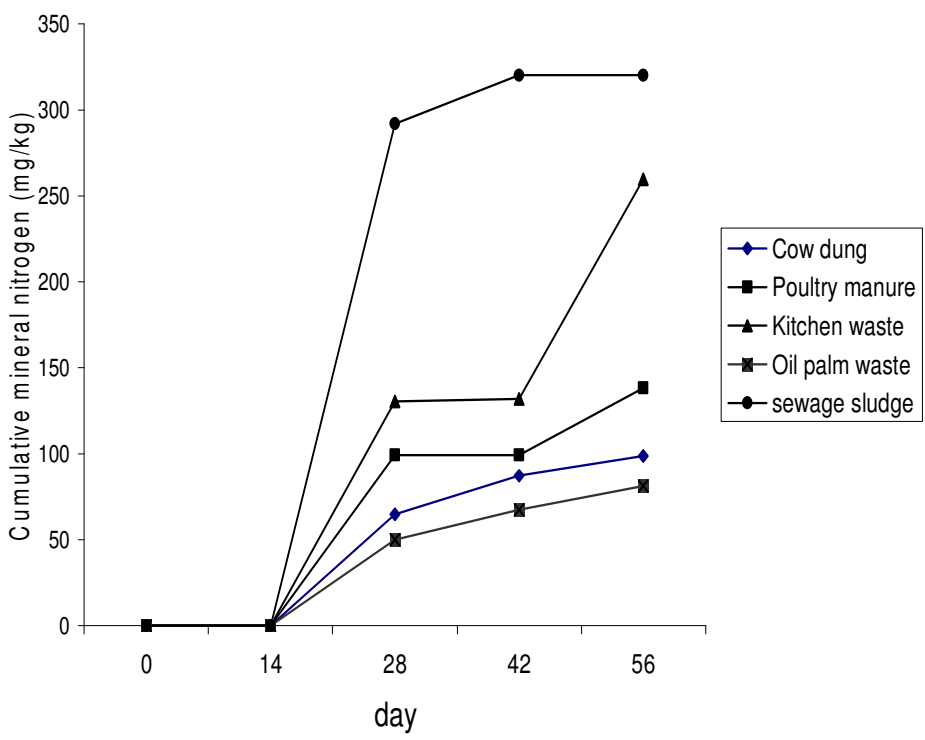

Fig 3: Cumulative nitrogen mineralization in mangal acid sulphate soil amended with organic wastes 
Mineralization of Nitrogen in Hydromorphic.....

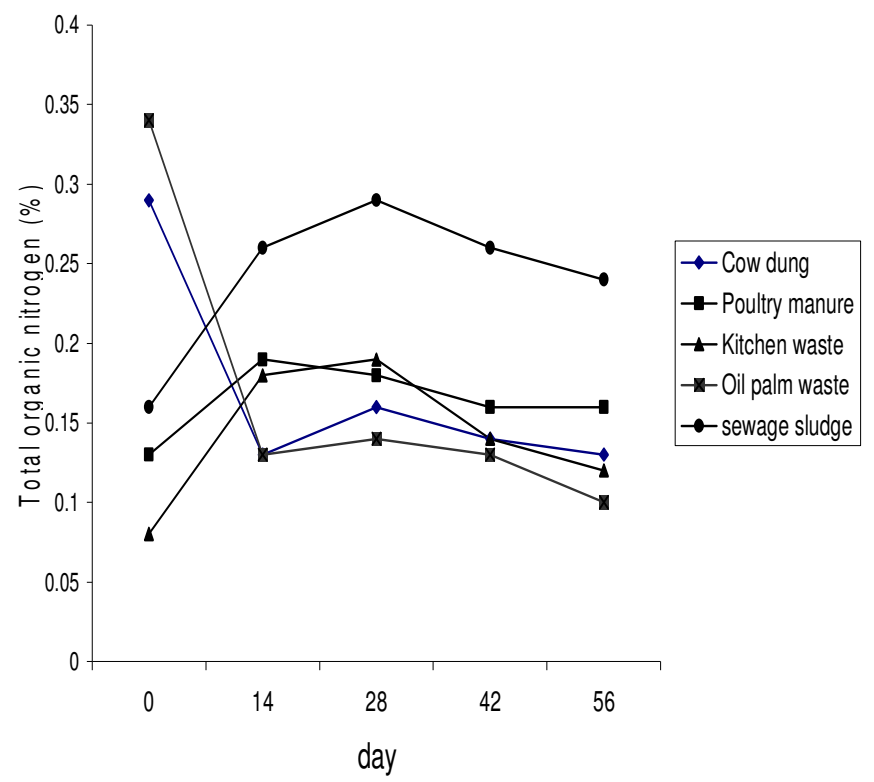

Fig 4a: Changes in total organic nitrogen in fadamal soil amended with organic wastes

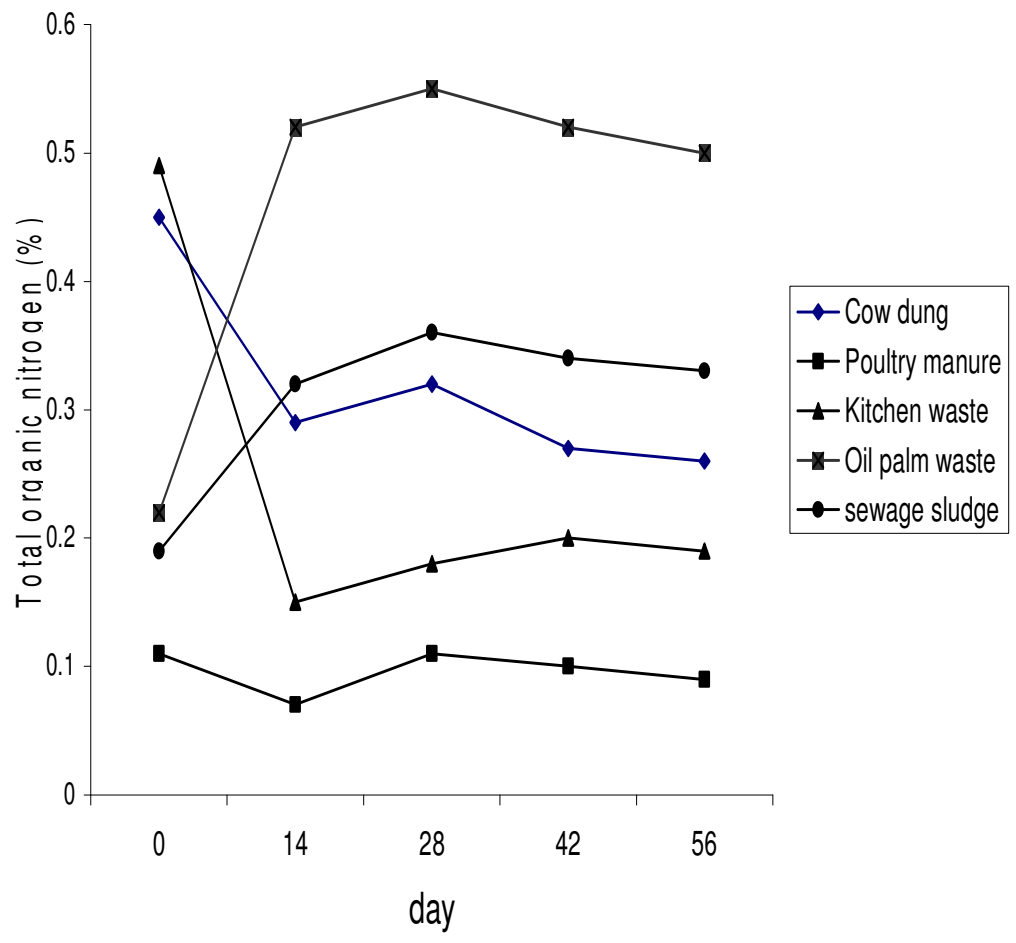

Fig 4b: Changes in total organic nitrogen in meander belt soil amended with organic wastes 


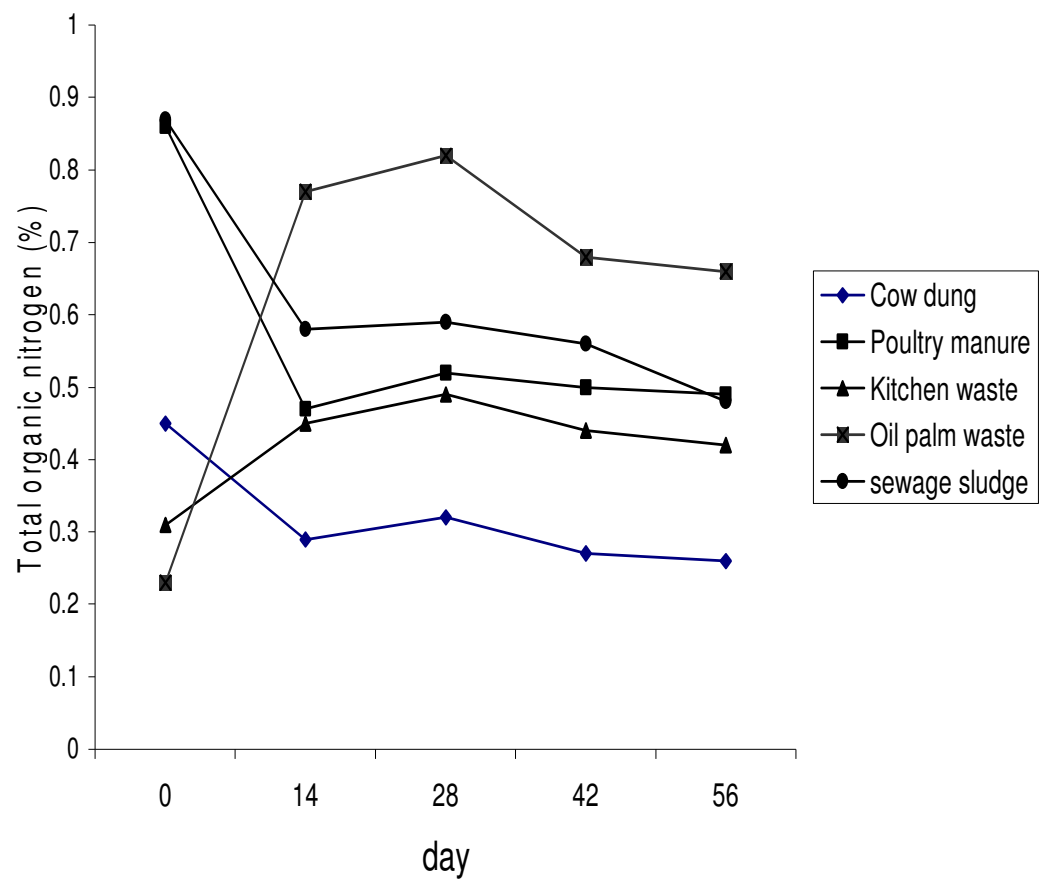

Fig.4b: Changes in total organic nitrogen in mangal acid sulphate soil amended with organic wastes.

Chae and Tabatabai (1986) have also reported low mineralization value for fresh cattle manure in soil; the manure used was probably mixed with urine. They found about $1.4 \%$ mineralization of organic nitrogen after 8 weeks with figure increasing to $13 \%$ after a long-term incubation. Similarly in this study cow manure showed the least value of nitrogen mineralization.

Figures $4 \mathrm{a}, 4 \mathrm{~b}, 4 \mathrm{c}$ illustrates the changes in total organic nitrogen with respect to incubation time for fadamal, meander belt soil, and mangal acid-sulphate soil respectively. There was a marked decrease in the total organic nitrogen during the incubation period. The changes in the total organic nitrogen after 28 days reflect increased conversion of organic nitrogen to inorganic forms as a result of increased microbial activities (Brady, 1974). The decrease in total organic over incubation period showed a remarkable difference among the various soil and waste types. This is due to the differences in the physicochemical properties of the different soil and wastes. Total organic nitrogen and $\mathrm{C}: \mathrm{N}$ ratio showed negative significant correlation with nitrogen mineralized $(\mathrm{P} \geq 0.05 \mathrm{r}=-0.33$ and $\mathrm{r}=0.92$, respectively $)$

The results obtained indicate that $\mathrm{N}$ mineralization in organic waste-treated soil is highly dependent on the composition of the organic waste and the chemical and physical make up of the soil receiving the organic waste.

\section{REFERENCES}

Bremmer JM; Mulvaney CS 1982. Nitrogen-Total. In: Page AL, Miller RH, Keeney DR (Eds).Methods of Soil Chemical Analysis,Part2: Chemical and Microbiological Properties, Monograph No 9,(2nd Edn). American Society of Agronomy.-Soil Science Society of America, Madison,Wisconsin, U.S.A pp 595-624.

Chae YM; Tabatabai MA 1986. Mineralization of nitrogen in soil amended with organic wastes. $J$. Environ. Qual. 15:195-198.

Cheschair GM, Westerman PPW, Safley JIM 1986 .Laboratory method for estimating available nitrogen in manure and sludge. Agric. Wastes 18:175-195.

Christenen BT; Olesen JE 1998. Nitrogen mineralization potential organic mineral size separated from soils with annual straw incoporation. Eur J. Soil Sci. 49:25-36. 
Gale PM; Gilmour JT 1986. Carbon and nitrogen mineralization Kinetic of poultry litter. $J$. Environ. Qual. 15:423-426.

Haque I; Walmsley D 1972. Incubation studies on mineralization of organic sulphur and organic nitrogen. Plant Soil 37:255-264.

Herbert M; Karam A; Parent LE 1991 Mineralization of nitrogen and carbon in soils amended with composted manure. Biol. Agric Holtic. 7:349361.

Iwegbue CMA; Ekakitie AO; Egun AC 2006. Mineralization of nitrogen in wetland soils of the Niger Delta amended with water hyacinth (Eichhornia spp) waste. Int. J. Soil Sci. 1(3): 258-263.

Kachaka S; Vanlauwe B; Merckx R 1993. Decomposition and nitrogen mineralization of pruning of different quality In Mulongoy .K. and Merckx R (Eds) Soil organic matter dynamics and sustainability of Tropical Agriculture. John Wiley and Sons Ltd, Chichester, U.K pp 199208.

Keeney DR; Nelson DW 1982 Nitrogen-Inorganic forms In Page A.L., Miller R.H. and Keeney DR (Eds).Methods of Soil Chemical Analysis,Part2: Chemical and Microbiological Properties, Monograph No 9,(2nd Edn). American Society of Agronomy.-Soil Science Society of America, Madison,Wisconsin, U.S.A pp 642-698.

Madrid F; Lopex R; Cabrera F; Murillo JM 2001 Nitrogen Mineralization for assessing the correct agricultural use of M.S.W. compost. Orbit .J. 1:1-10

McLean EG, 1982 .Soil pH and Lime Requirement. In Page A.L., Miller R.H. and Keeney D.R. (Eds).Methods of Soil Chemical Analysis,Part2: Chemical and Microbiological Properties, Monograph No 9,(2nd Edn). American Society of Agronomy.-Soil Science Society of America, Madison,Wisconsin, U.S.A pp 199-224
Murwira H; Kirhman H 1993. Carbon and nitrogen mineralization of cattle manures, subjected to different treatments, in Zimbabwean and Swedish soils. In Mulongoy $\mathrm{K}$ and Merckx $\mathrm{R}$ (Eds.) Soil organic matter dynamics and sustainability of Tropical Agriculture John Wiley and Sons Ltd., Chichester, U.K pp 189-198

Nelson DW; Sommer LE 1982. Total Carbon, Organic Carbon and Organic Matter. In Page A.L., R.H. Miller and D.R. Keeney (Eds).Methods of Soil Chemical Analysis, Part 2: Chemical and Microbiological Properties, Monograph No 9,(2nd Edn.). American Society of Agronomy.-Soil Science Society of America, Madison, Wisconsin, U.S.A pp 539-576

Nogales R; Gallardo-Lara LE; Delgado M 1982. Aspectos Fisicoquimicos y Microbiioe u sicos del compostaje de basuras urbanas. Anales de Edafologia y Agrobiologia 41:1169-1174.

Pettygrove, GS; Doane TA; Horwath WE; Wu, JJ; Mathews MC; Meyer DM 2003. Mineralization of nitrogen in dairy manure water. Western Nutrient Management Conference 2003 Salt Lake City, UT 5: pp 36-41.

Reeuwijk LP 1995. Procedure for soil analysis. Technical paper 9, 5th ed ISRIC Wageningen. The Netherland.

Rubuduka EB; Cadishch G; Giller G 1993. Mineralization of nitrogen in woody legume pruning and its recovery by maize In Mulongoy $\mathrm{K}$ and Merckx $\mathrm{R}$ soil organic matter dynamics and sustainability of Tropical Agriculture John Wiley and Sons Ltd., Chichester,UK pp 181-188. 